


\section{THE BLOOD OF STRANGERS}

Stories from Emergency Medicine

F R A N K H U Y LER

UNIVERSITY OF CALIFORNIA PRESS

Berkeley • Los Angeles • London 
University of California Press

Berkeley and Los Angeles, California

University of California Press, Ltd.

London, England

(C) 1999 by the Regents of the University of California

Library of Congress Cataloging-in-Publication Data

Huyler, Frank, 1964- .

The blood of strangers : stories from emergency medicine / Frank Huyler.

p. $\mathrm{cm}$.

ISBN 0-520-21863-9 (alk. paper)

1. Emergency medicine-Popular works. 2. Hospitals-Emergency service-Popular works. I. Title.

RC87.H975 1999

$616.02{ }^{\prime} 5-\mathrm{dc} 21$

98-39973

CIP

Manufactured in the United States of America

$\begin{array}{llllllllll}10 & 9 & 8 & 7 & 6 & 5 & 4 & 3 & 2 & 1\end{array}$

The paper used in this publication meets the minimum requirements of ANSI/NISO Z39.48-1992 (R 1997) (Permanence of Paper). 
For my father and mother, Frank and Marina Huyler 
